\title{
A Constraint-based Analysis of Obligatory Contour Principle in Anaang Morphological Constructions
}

\author{
Unwana Akpabio \\ Department of Linguistics, Igbo and Other Nigerian Languages, University of Nigeria, Nsukka, Nigeria \\ Olusanmi Babarinde \\ Department of Linguistics, Igbo and Other Nigerian Languages, University of Nigeria, Nsukka, Nigeria \\ George Iloene \\ Department of Linguistics, Igbo and Other Nigerian Languages, University of Nigeria, Nsukka, Nigeria
}

\begin{abstract}
The obligatory contour principle forbids identical consecutive features in the underlying representation. This work undertakes a description of the Anaang tonal structure, the tonal behaviour of compounds and reduplicates in the language, bearing in mind their sensitivity to the OCP and the environments that trigger the adherence. An adapted Ibadan wordlist of 400 Basic Items (Trial) English version was used via interview for data collection from six men and six women within Abak Local Government Area in Akwa Ibom State. The data were analysed using optimality theoretical framework. The analysis shows that Anaang compounds as well as reduplicates exhibit cases of tonal modifications in line with OCP. For compounds, the tone of the second noun changes depending on the tonal sequence. In the HH noun base, the second-high tone of the second noun changes to a low tone, in the LH noun base, the tone of the second noun is raised to a down-stepped high tone, the LL noun base sees the tone of the second noun being raised to a high tone. For reduplication, the tone of the $L$ verb base changes when the reduplication is partial. When the reduplication is complete, the high tone of the second noun is down-stepped.
\end{abstract}

Index Terms-Annang language, obligatory contour principle, compounds, reduplicates, tone

\section{INTRODUCTION}

The study of language has proven that language is one of the most versatile areas of human research, yet one cannot say that linguistic researches are enough as there are countless languages that little or nothing have been done in and on them. Also, new areas of concerns and interests such as the Obligatory Contour Principle henceforth (OCP), a concept that is applied at different levels of linguistics has been ongoing. In autosegmental phonology, Leben (1973) pioneered a principle to forbid two identical tones from being adjacent at the tonal level in the analysis of Tiv verbal systems. He was of the opinion that a sequence of tones such as a High High Low (HHL) is impossible in the language since the principle rules it out. Goldsmith (1976) calls this phenomenon the "Obligatory Contour Principle" and states thus: at the tonal level of the grammar, any two adjacent tones must be distinct. Therefore, HHL is not an impossible tone pattern, it automatically simplifies to HL. The status of OCP has been debated in autosegmental phonology and Goldsmith (1995) concludes that because the OCP is a 'soft' universal principle, the problem of the universality of OCP is not resolved within the framework of autosegmental phonology. Oostendorp (2005) had made a typological study of the OCP in features and examined the OCP in autosegmental phonology. He discussed OCP in optimality theory (OT). In OT, the case of the universality of the OCP constraint as a property of UG which is so central to autosegmental phonology is not a problem within the OT framework. According to him, this is because OT allows for constraint violation, therefore the OCP will be expected to be achieved when it is ranked highly enough to be respected, while it will be violated when it is ranked lower than some other constraints that must be satisfied. The OCP can be studied at different levels: segmental, featural, or suprasegemental.

Tone which is the use of pitch to distinguish the meaning of words is used in some $70 \%$ of the world's language (Yip, 2006). It is controlled by the larynx. Language may contrast at least four level tones, and at least two different rises and falls which are high ['], low ( $)$ ) high low $\left({ }^{\wedge}\right)$, low high $\left({ }^{\vee}\right)$. In phonology, tone operates at a different level independent of the segments of the word, showing remarkable mobility and stability under segmental selection. Rising and falling tones are not indivisible but arise when two different level tones appear on the same syllable. Conversely, one tone can spread over several syllables, creating a tonal plateau.

Udoh, (2012) states that the Anaang language is a member of the Lower Niger Congo language. It belongs to the (New) Benue Congo subfamily of the Niger Congo phylum. This research work intends to look at the tonal behaviour 
of two morphological constructions namely: compounds and reduplication and to identify the phonological environment that triggers its sensitivity in the language.

\section{MethodologY}

This research design is qualitative. The purposive sampling method was employed. Twelve aged native speakers who reside permanently in the Anaang speech community were sampled. Data were collected through structured interview and carefully analysed using the tenets of optimality theory.

\section{LITERATURE REVIEW}

\section{A. SPE Generative Phonology}

The grammar of a language is an explicit theory of the intrinsic linguistic ability of the ideal speaker-hearer of that language. This grammar must generate the infinite number of well-formed sentences and must assign a structural description of such sentence. Generative phonology (GP henceforth) is a theory of phonology within the framework of generative grammar. The tenets of this approach were made prominent in Chomsky and Halle's (1968) The Sound Pattern of English (SPE). Generative phonology is concerned with principles that guide the pronunciation of words, segments, phrases and even sentences and how they are derived from more general principles, which are operative in all languages. Mainly, the suppositions of generative phonology are that:

a. phonological structure portrays the linguistic competence of the individual native speaker to work out a phonetic representation for the possible infinite number of sentences which can be generated through the syntactic component of the grammar of the language; and

b. this competence can be scientifically investigated.

The weaknesses of generative phonology lie in its linearity condition where sound segments are sequentially treated, one after the other. As a result of this, suprasegments which cannot be separated from the segments in utterances are not accounted for in generative phonology of SPE.

\section{B. Lexical Phonology}

Lexical phonology developed by K.P. Mohanan and P. Kiparsky in the early 1980s is most similar to classical generative phonology (Udema, 2004). In this theory, the lexicon plays a key role and that characterises a significant departure from classical models. Lexical phonology is an approach that accounts for the interactions of morphology and phonology in the word-building process and the approach is based on the insight that much of the phonology operates together with the word formation rules in a cyclic fashion to define the class of lexical items in a language. Wordformation rules relate to the formation of words. These rules then combine morphemes to create new words and they are also called morphological rules.

Udema (2004) explains that the term lexicon simply means 'dictionary', but in the linguistic perspective the lexicon also represents information about pronunciation, meaning, morphological and syntactic properties so that it could be called a 'mental lexicon'. Moreover, in lexical phonology, the lexicon is considered as being more than just an appendix to the grammar, containing unpredictable idiosyncratic phonological, grammatical, semantic and lexical information about morphemes and lexical items. Prior to the development of lexical phonology, another theory was trending in the study of linguistics called generative phonology.

\section{Autosegmental Phonological Theory}

Autosegmental phonology is a 'nonlinear' or multi-tiered approach to phonological analysis. Rather than restricting an analysis to a single linear representation and being unable to effectively force suprasegmental phenomena, such as tone, onto a given segment's representations, Goldsmith proposes that linguistic data are more effectively analysed as parallel sequences in which one tier represents suprasegmental data (e.g. tone). These tiers are tied together by means of association lines. The key concepts of the theory according to Goldsmith include 'segment, feature, rule, and association'. The theory includes a well-formedness condition that applies to derivations which writes, adds or deletes "association lines at any point throughout the derivation".

The basic assumption of autosegmental phonology is that phonological features or units whose relationship "is merely one of simultaneity in time" can be separated into different levels, also called tiers, and their relationship indicated by association lines. Autosegmental phonology was originally developed to describe the behaviour of tone, but it was also found to be useful in describing other phonological phenomena, such as vowel harmony. Since the initial development of autosegmental phonology forty years ago, the theory has been used almost exclusively to describe the behaviour of tone in language.

\section{Interaction of some basic properties assumed in autosegmental phonology}

(i). Assimilation as spreading: Hyman (2013) states that, whether concerning tone, vowel harmony or other processes, assimilation is captured by spreading a feature from one anchor to another, represented by a clashed association link. This goes against the earlier view represented by SPE (Chomsky \& Halle 1968) where assimilation was expressed through feature copying, as seen in below: 
1.<smiles>[Y][In][Te]</smiles>
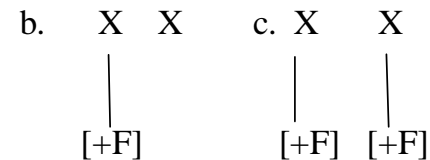

(ii). No Line Crossing: Goldsmith $(1976 \mathrm{a}, \mathrm{b})$ has it that a second property concerns the prohibition against association lines crossing each other. Hyman, (2015) mentions that this view by Goldsmith has been critically evaluated by Coleman \& Local (1991) that most practicing phonologists continued to assume that assimilation by spreading could not produce representations.

(2)<smiles>[Y]C([Y])([In])[IH]</smiles>

(iii). A branching element: a succession of two identically linked elements. The third property made possible by autosegmental phonology was the distinction between the representations, Hyman (2013).

(3) a

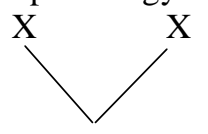

$[+\mathrm{F}]$ b)

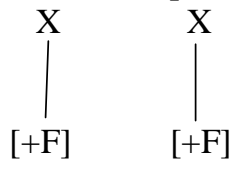

\section{Optimality Theory}

In contrast to autosegmental phonology, OT is not primarily a theory of representations, but a theory of how wellformedness conditions on how representations interact to account for phonological processes (Downing, 2009). An optimality grammar can be thought of as a function that maps underlying forms to surface forms. The emergence of optimality theory has introduced new ways of thinking about these fundamental issues in phonology and syntax. OT consists of some basic elements; a generator (Gen) which generates or manipulates the actual linguistic form to produce a number of forms which serves as inputs, but it is not deterministic of individual languages but that of the typological space of all-natural languages. Whichever structure is selected as the output of a particular grammar is determined by the relative strength of very general but violable constraints external to GEN, given the language particular constraints strengths. Two different kinds of constraints are identified by McCathy, (2007:1);

i. processes can be blocked by input constraints.

ii. process can be triggered by output constraints.

Despite the fact that blocking and triggering relationships between the processes and output constraints are easy to grasp, it is not obvious how to express these relationships formally in linguistic theory. McCarthy, (2007) avers that this is in fact, the point where phonological and syntactic theory diverged.

\section{The fundamentals of Optimality Theory}

McCarthy (2007) outlines some questions OT seeks to answer and their answers as well.

i. How are constraints on the output of the grammar satisfied?

ii. What is the relationship between constraints on output structures and the operations that transform inputs into outputs?

iii. How are triggering and blocking effects accounted for?

iv. What is the relationship between the universal and the language-particular constraints?

v. How can constraints differ in their activity from language to language? (p. 4).

The answers to these questions, according to McCarthy (2007) follow directly from the fundamental properties of OT.

- OT places severe limits on the abstractness of phonological analyses. In classic OT, there are only two levels of representation; the input and output. This contrasts with pre-OT derivational theories, which placed no limit on the number of intervening levels.

- A set of faithfulness constraints evaluates the identity of inputs and outputs.

- Differences between input and output must be motivated by higher ranked markedness constraints.

- Predictable input features cannot be underspecified in OT; instead, all forms of output predictability must be expressed as markedness constraints. Only unpredictable and/or invariant features of the input can be inflexibly specified. For these reasons, the relationship between inputs and outputs is necessarily more transparent in OT than was required in derivational theories constraints.

- OT also places severe limits on the arbitrariness of phonological processes. Processes are motivated by markedness constraints: testable, cross-linguistically valid hypotheses about output well-formedness. Because faithfulness constraints penalise changes between the input and the output, and markedness constraints are the only motivation for changes.

- OT makes the strong claim that phonological processes should result in improvements in output wellformedness. 
- The role of morphology in conditioning phonological processes has also become more prominent and explicit.

- Prosody-morphology alignment constraints play an important role in OT analyses of prosodic morphology processes like infixation and reduplication and prosodic phonology processes like featural affixation.

- A principle of OT which makes the theory of particular interest to comparative linguists is the proposal that OT analyses yield testable factorial typologies. What is meant by this is that a language-particular grammar consists of a ranked set of universal constraints. Re-ranking the constraints developed to account for any specific language yields a set of alternative grammars which should, in fact, define a typology of existing grammars for other languages. Alternative cross-linguistic or cross-dialectal outputs for identical inputs should also be analysable by re-ranking a shared set of constraints. Factorial typologies derived by constraint re-ranking are then, intended to be not only a way of testing particular OT analyses, but also provide a way of formalising the range of possible cross-linguistic variation for a particular process.

- Finally, even though OT is not a theory of representations, we do find innovations in the representation of tone which are most sensibly implemented in OT, as Leben (2006) points out. It has also led to innovations in the representation of vowel harmony and reduplicative morphemes (Downing, 2009).

\section{TONE}

Tone languages are defined by Hyman (2001) as languages in which an indication of pitch enters into lexical realisation of at least some morphemes. This infers that tone may be part of the lexical information of words themselves but that it can also carry information on other levels of linguistic analysis, including phonology, morphology, syntax, semantics and pragmatics (YIP, 2002, p. 12). The functions of tone are generally subdivided into lexical and grammatical functions. Lexical tones refer to pitch differences that distinguish the meanings of lexical items from one another. This makes tone a crucial part of the lexical representation (YIP, 2002). Morphological tone is described as tone that in itself carries a measure of independent meaning. Taking this line of thought further, syntactic tone can be seen as pitch patterns that carry a measure of independent functions when it indicates for example syntactic functions or syntactic boundaries. Pragmatic tone can be seen as tone that might distinguish statements from questions (see Salffner, 2009).

\section{The Obligatory Contour Principle}

The obligatory contour principle is a phonological concept that states that consecutive identical tones are banned in underlying representations. Two adjacent tones must be distinct. While OCP allows tonal structures like ' $\mathrm{H}$ ', 'HL', 'L', 'LH', 'LHL', etc., depending on the syllable structure of the language in question, it disallows structures like 'HH', or HLHLLH'. Therefore, in a situation where vowels in one word are pronounced at the same pitch there is only one way out: these vowels are linked to the same tone.

Oostendorp (2005) in his manuscript entitled Obligatory contour principle gives an OCP related rule in some Bantu languages which is called Meeussen's Rule (named after The Belgian Bantuist Achilles Emile Meeussen, (1912-1978). This rule can be illustrated by the following example from Kirundi.

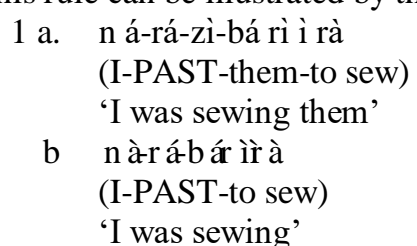

In (1a), the high-toned tense marker rá and the stem bárìrà, which also starts with a high tone, are separated by a low tone agreement marker ' $z i$ '. Nothing happens here; we may assume that this form represents the underlying state of affairs quite faithfully. In (1b), on the other hand, the tense marker ' $r a$ ' and the stem 'barii' are adjacent. As a result of this, the second-high tone has to go. Oostendorp boldly avers that it is quite obvious that Meeussen's Rule is an OCP effect: two high tones which are adjacent are not allowed. The way to solve the OCP problem here as he continues is to turn one of the two 'bad' tones into a good tone, giving an alternation of high and low tones.

\section{Data PRESENTATion AND ANALysis}

\section{A. Anaang Tonal Structure}

Anaang has both register and contour tones. It displays five tonal structures viz, the high register tone $\{\mathrm{H}\}$, the low register tone, $\{\mathrm{L}\}$, the rising and falling contour tone $\{\mathrm{HL}\}$, the falling and rising contour tone $\{\mathrm{LH}\}$ and the downstep high tone $\{! \mathrm{H}\}$.

\section{the high tone}

The high register tone in Anaang can be seen in deferent syllable patterns. Let us consider the following;

2 a. /tád/ 'unlock'

b. /dád/ 'take'

\section{the low tone}

3 a. /nìm/ 'keep' 
b. /bj̀/ 'take'

\section{the rising and falling contour tone}
4 a. /kâl 'go'
b. /ànwênwèn/ 'black'

the falling and rising contour tone
5 a. /akpǒ/ á non- initiate
b. / íkp̌̌/ á rope used to climb trees
the down-step high tone
6 a. /á!boón/ 'king'
b. / ú!boón/ 'glory'

Out of these five patterns, three are register tones while two are contour tones. The examples below show the high register tone.

7 a. /tá / 'chew'

b. /ébód / 'goat'

Looking at the data presented above from $(7 \mathrm{a} \& b)$, we observe that the high register tone can be found in all syllable types, that is, both the light and the heavy syllables.

The following exemplifies the low register tone;

8 a. /tèm/ 'cook'

b. /èkpàd/ 'bag'

The examples above show that the low tone is found in monosyllabic words as well as disyllabic and trisyllabic words and even more.

The rising and falling contour tone is illustrated thus;

9 a. $/ \mathrm{ka} / \mathrm{go}$

b. /ànweywen/ 'black'

Let us consider the falling and rising tone instances below;

$10 \mathrm{a}$. /akpo/ á non- initiate

b. /íkpo/ á rope used in climbing trees

The falling and rising contour tone appears on monosyllabic and disyllabic words.

Examples from the downstep tones are seen below;

11a. /ýk!eén / 'dregs'

b. /ú!boón/ 'glory'

The downstep high tone is a unique feature of the Anaang tonal structure because not all tone languages have the downstep. In Anaang, a high tone is lowered slightly so that the second-high tone is not as high as the first one and not too low to become a low tone. This tone is seen in disyllabic words only as seen in the examples above.

\section{B. Morphological Constructions in Anaang}

\section{1. compounds}

This morphological process is very productive in Anaang as it is used to form lots of new words. The combination in compounding can be that of noun + noun, verb + noun, noun + verb, noun + adjective, noun + adverb etc. It is worthy of mention that the derived words may be endocentric or exocentric. In endocentric compounds, meanings are derived from the meaning of the individual words combined to form it. Consider;

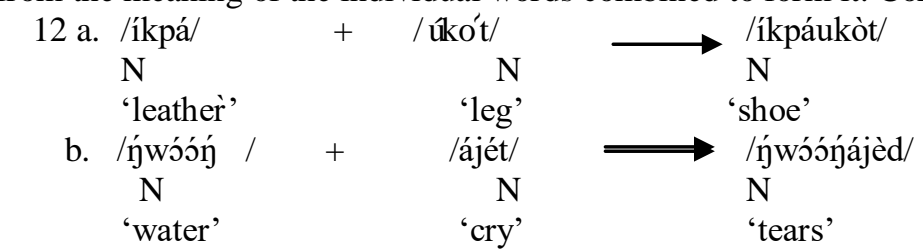

According to Bloomfield (1933), Williams (1981), Selkirt (1982) Spencer (1991), Lieber (2010), an endocentric compound's meaning is easily derivable from its head, therefore a word like ǵwóśn' 'water' is easily known by the language users since the head ájét 'cry' has a great contribution to the whole meaning of the newly formed word. Let us now consider another set of compounds known as exocentric.
13a. /ínuà/ 'Mouth'
b. /àtfóp/ 'Fast'
c. /ilíp/ 'Belly'

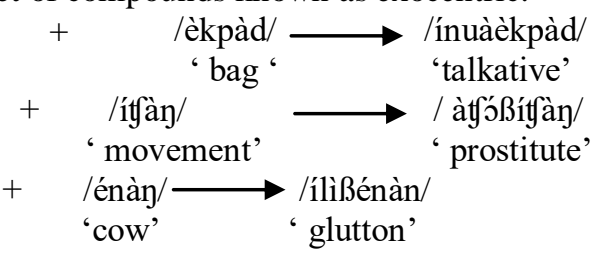

Exocentric compounds as observed by Katamba (1993) are those whose meanings are opaque that are quite different from their respective heads and Lieber readily observes that this kind of compounds are less attested compared to its endocentric counterpart. Let us consider the compound word /àt'’́ßitfày/ 'prostitute' one especially (those who do not have the language in question as their first language) would not readily know that the word is referring to a 'prostitute' 
since its parts làt J'p/ 'one who moves fast' and 'litày/ movement' do not have any bearing as regards the word 'prostitute,' also linking 'bag' èkpàd' and 'mouth' inuà in view of the word talkative is quite opaque. Exocentric compounds are often used to relate derogatory circumstances. Therefore, to some extent, they are euphemistic because àt’’’ßit ày is lighter than 'àpàrà for prostitute.

However, some word classes that can be compounded. Based on our data, we discovered that Anaang compound words can have $\mathrm{N}+\mathrm{N}$ combination to form an $\mathrm{N}$ as in;

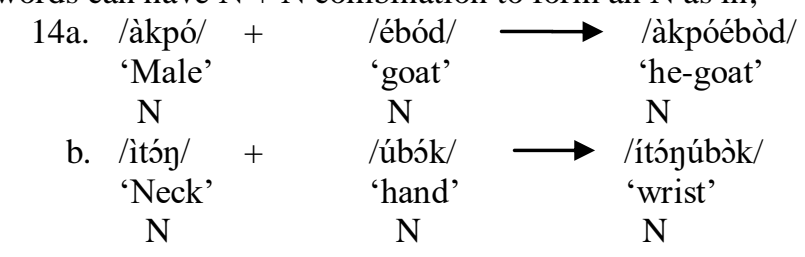

We can also have such combinations as $\mathrm{V}+\mathrm{N}$ as seen in the following examples:
c. /b̀̀/
'Take'
/úfèn/
/bòúfèn/
$\mathrm{V} \quad \mathrm{N}$
d. /tók/ +
'Urinate'
$\mathrm{V}$
/ńkúm/
'urine'
$\mathrm{N}$
/tókńkúm/
'urinate'

Adjectives can also combine with nouns to form new words as the following examples show
e. /ỳjóng/
'Strong'
Adj.
f. /ínném/ +
'Sweet'
Adj
/ílem/ $\longrightarrow$ /ìtónílèm/
'body'
'healthy'
$\mathrm{N}$
Adj
létfid/
'heart'
$\mathrm{N}$ $\begin{aligned} & \text { /ìnnèmetfid/ } \\ & \text { 'happiness' } \\ & \mathrm{N}\end{aligned}$

Examples above show that only content words are used in Anaang compounds.

\section{Tone in compounds}

It is observable from the examples above that OCP is prevalent. It manifests in the $\mathrm{N} 2$ of the compound; the first set of the base changes from $\mathrm{HH}$ to $\mathrm{HL}$. Here the change in the contiguous tone is manifested in the last tone of the compound word - that is, its environment. The following examples demonstrate our claims.
15a. /áwó/ 'person"
b. /íkél 'hemp'
c. /ńnón/ 'maggot'
$+\quad$ lékón/ 'army/war'$$
\text { + /ékpó/ }
$$$$
\text { 'ghosst' }
$$$$
+\quad \text { lítól }
$$
'toilet'

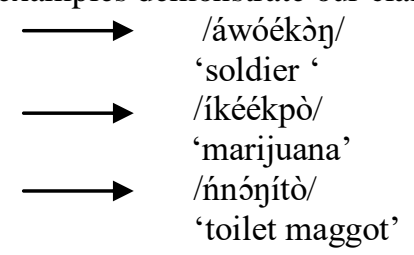

The data above show four tone-bearing words and it is observed that OCP lowers the last tone of the second compound thereby making it a low tone.

\section{a. The HL-LL sequence}

Though OCP in Anaang is mostly manifested on the N2 but there are exemptions in which, for instance, the first tone is affected. There are also cases where the second or third tone is affected. In the above-mentioned sequence, that is, the $\mathrm{HL}$ - LL sequence, the LL sequence changes to an HL. Consider the following examples;
17a. /úfòk/
HL
ufjo/
$+$
LL
HL HL
b. /'́fì̀k/
'wisdom'
$+\quad$ lǹwèd/
'book'
$+\quad$ /ǹwèd/
'book'
c. /úfj̉k/,
/àkàm/
'prayer'

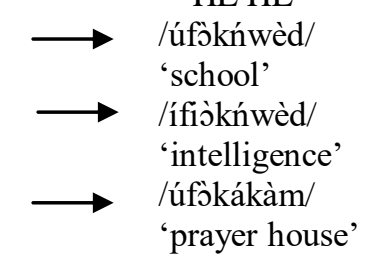

Examples given above demonstrate the rising of a low tone to a high tone. Tableau 1 below shows how this is made possible:

\begin{tabular}{|c|c|c|c|c|}
\hline \multicolumn{5}{|c|}{ TABLEAU 1} \\
\hline & úfỏk -ákàm & OCP_N2 TI & IDENT-10(S) & IDENT-10(Tone) \\
\hline a. & ùfök - álàm & & $*$ & $* !$ \\
\hline b. & úfòk - àkàm & $* !$ & & $*$ \\
\hline c. & úfòk - ákám & & & $* !$ \\
\hline d. & ufj̀k - ákàm & & & $*$ \\
\hline e. & úfòk - àkám & $* !$ & & $* *$ \\
\hline
\end{tabular}


Clearly the optimal candidate from tableau 1 is (d) because it violated only once. Constraints are arranged across the top of the tableau in a hierarchy of decreasing importance from left to right. It did not also violate the highest ranked constraints. OCP-N2T1 simply says, assign a violation sign if the candidate fails to change its tone from low to high. The optimal candidate, that is, the well-formed compound in Anaang for this set is (d). Having considered cases and environment of OCP in compounds, let us now examine the environment of OCP in reduplicates.

\section{b. The RED-base}

Anaang manifests OCP in reduplication when the base has a low tone. The reduplicated form changes from a low tone to a low-high tone. Consider the following:

$\mathrm{L}$

18 a. /mùm/ 'hold'

b. /dùd/

'drag'

c. mèn/

'give birth'
LHL

/mùúmùm/

'just hold'

/dùúdùd/

'drag (emphatic)'

/mèémèn/

'give birth instead'

The data presented explicate the workings of OCP in Anaang reduplicates. The constraint that allows or denies this environment is given thus;

TABLEAU 2

\begin{tabular}{|c|c|c|c|c|}
\hline & RED - mèn & $\mathrm{LH} \leftarrow \mathrm{L}(\mathrm{RED})$ & $*^{*} \sigma \mathrm{N}$ & NO CODA \\
\hline a. & mèé-mèn & & & $*$ \\
\hline b. & mèè-mèn & $* !$ & & $*$ \\
\hline c. & méè-mén & $* !$ & & $*$ \\
\hline d. & mén-mèn & $* !$ & & $*$ \\
\hline e. & mê-mén & $* !$ & $*$ & $*$ \\
\hline
\end{tabular}

The optimal candidate for this competition is candidate (a) since it did not violate the highest ranked constraint. All others were knocked out for fatal violation. Anaang partial reduplicates of monosyllabic words with low tones exemplifies neatly for OCP.

3. Sensitivity of Anaang compounds to the OCP

a. The H.H base

Considering the sensitivity of OCP in Anaang compounds, we have seen the change from a HH sequence to a HL sequence in the second noun of the compound. Consider the following examples

\section{$\mathrm{H}$}

19a. /ákpá/ 'body'

b. /íkpá/ 'skin'

c. /íkpá/ 'leather'

$$
\mathrm{H}
$$

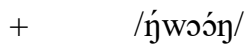

'water'

/úkód/

'leg'

$+\quad$ /itfin/

'waist'
HH HL

/ákpáńwò̀y/

'ocean'

/íkpáúkòd/

'shoe'

/íkpáitfìn/

'belt'

From examples given above, observe a pattern in the second noun (N2). In the noun ákpá 'body' and ýwón 'water', all have high tones but when compounded, the tone of the second noun changes. The tone instead forms a high (H) and Low (L) pattern. The descriptive generalisation we can give here is that in Anaang, during compounding, a $\mathrm{HH}$ sequence becomes HL.

The constraint responsible for the alternation is basically a markedness constraint (MCON). The MCON can be stated thus; HH becomes HL (N2 compound). This is read as the HL sequence of the surface form obtained from the $\mathrm{HH}$ base in the N2. We generate five candidates that will undergo the constraint test and see the well-formed structure considering OCP. Recall that in all the tableaux used in the analysis, the constraints are ranked in the order of decreasing importance.

TABLEAU 3

\begin{tabular}{|c|c|c|c|c|}
\hline & íkpá -úkód & 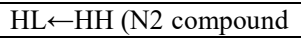 & MAX-10 (s) & IDENT-10(TONE) \\
\hline A & İkpá -úkòt & & & $* !$ \\
\hline $\mathrm{B}$ & Îkpá -kòt & $* !$ & $*$ & $* *$ \\
\hline $\mathrm{C}$ & Îkpá -úkót & $* !$ & & $*$ \\
\hline $\mathrm{D}$ & íkpá -úkòd & $* !$ & & $* *$ \\
\hline $\mathrm{E}$ & íkpá -úkòd & & & $*$ \\
\hline
\end{tabular}

Candidate (e) in Tableau 3 satisfied OCP by turning the consecutive high tone /íkpál + /úkód/ to a low tone on the last syllable /ikpáúkòd/. The CON formed constraints that aid the EVAL to evaluate and bring out (e) as the optimal candidate. The first column had the candidates, followed by the MCON HL $\leftarrow$ HH (N2 compound) and the FCONMAX-10(s) and IDENT-10 (tone). The MCON was explained earlier but let us now explain the two others. FCONs. MAX-10(s) means, do not delete the segments of the base while IDENT-10(tone) means that the tones in the output 
should be identical with that of the input. Using the three CONs, we are able to arrive at the optimal candidate (e). The $\mathrm{HH}$ base is very sensitive to OCP as demonstrated earlier.

\section{b. The LH base}

Another interesting work of the OCP is seen in its ability to raise a low tone to a down-step high tone.

$\mathrm{H}$
20 a. /íkpá/
'skin' $\quad \underset{\begin{array}{l}\text { lànón/ } \\ \text { 'up' }\end{array}}{\longrightarrow} \longrightarrow \begin{aligned} & \mathrm{H} \text { !H } \\ & \text { /'ikpá!ánón/ } \\ & \text { 'sky' }\end{aligned}$

Here, a LH base changed to a $\mathrm{H}$ !H ( $\mathrm{N}_{2}$ compound). It is very common to have sounds and suprasegments to undergo changes when in connected speech. This is simply what we observed here where a low tone is raised to a down-step high tone. This change can be represented in tableau 4 below.

TABLEAU 4

\begin{tabular}{|l|l|l|l|l|l|}
\hline & Íkpá- ánón & $\begin{array}{l}\text { LH } \\
\text { H!H(N2 compound) }\end{array}$ & MAX-BR(S) & DEP -10(S) & IDENT-10(TONE) \\
\hline A & Ǵíkpá - á!nóñ & & & & $*$ \\
\hline B & Íkpàt - ánóñ & $* !$ & $*$ & $*$ & $*$ \\
\hline C & Íkpà - àwóñ & $* !$ & & & $*$ \\
\hline D & Íkpà - ánóñ & $* !$ & & & $*$ \\
\hline
\end{tabular}

The optimal candidate for tableau 4 is (a) because it has not violated the highest ranked constraints $\{\operatorname{MAX}-\mathrm{BR}\{\mathrm{S}\}\}$.

\section{c. The LL base}

Words with the LL base are also affected by OCP because we observe that in the course of their undergoing compounding, there are changes in their tonal pattern. The LL sequence changes to a HL pattern. The following examples can suffice for our claims;

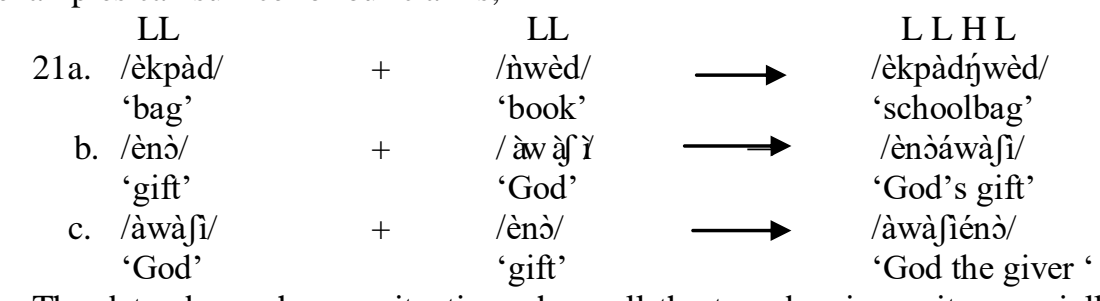

The data above show a situation where all the tone bearing units especially of the N2 carry low tones but during compounding, there is an observable change in such tone from LL to HL. Explaining these changes too using OT, we observe that OCP raises an underlying low tone to a high tone.

\begin{tabular}{|c|c|c|c|c|}
\hline & ènò - áwà $\int i$ & *LLL(N2 compound) & IDENT-10(tone) & MAX-10(tone) \\
\hline $\mathrm{a}$ & énò - àwá & $* !$ & $*$ & $*$ \\
\hline $\mathrm{b}$ & ènò - áwà $\int i ̂$ & & $*$ & \\
\hline $\mathrm{c}$ & ènò -áwásí & & $* * !$ & \\
\hline $\mathrm{d}$ & énó - áwá 1 is & & $* * ! *$ & \\
\hline $\mathrm{e}$ & ènò - àshì & & $* !$ & $*$ \\
\hline
\end{tabular}

Using McCarthy's way of explaining constraints and violation, he says, assign a violation sign $(*)$ if the candidate fails to meet a certain constraint. Now, considering our tableau 5, the first MCON states that a violation sign should be assigned to any candidate that has an LLL sequence. Candidate (a) violated the constraint. The FCON-IDENT-10 (tone) had many violations. The following FCON - MAX-10 (tone) decided the optimal candidate for the competition, the violation by candidate (e) left candidate (b) the winner of the completion. Therefore, candidate (b) is the acceptable and well-formed compound in the Anaang language. From our analysis of compounds so far, we have seen that they are quite sensitive to OCP.

\section{Reduplication in Anaang}

Reduplication is yet another fertile process in the Anaang morphology. It is a morphological process whereby the root or stem of a lexeme (or part of it) or even the entire word is repeated or reduplicated exactly or with a slight change. Reduplication is used in inflections to show a grammatical function, such as plurality, intensification etc., and in lexical derivation to create new words (Dutta \& Jindal, 2016).

In Anaang, reduplication is used when a speaker adopts a tone more 'serious' or figurative than ordinary speech and is also often, but not exclusively, iconic in meaning, Reduplication in this language can be described phonologically when discussing reduplicated segments (that is, sequence of consonants/vowels) or reduplicated prosodic units (syllables or moras). In addition to the phonological description, it is often described morphologically as a reduplication of linguistic constituents (i.e. words, stems, roots). The base is the word (or part of the word) that is to be copied, the reduplicated as RED. Reduplicated form is repeated only once as seen in table 1 below. 
TABLE 1

\begin{tabular}{|c|c|}
\hline \multicolumn{2}{|c|}{ TABLE 1} \\
\hline Verb Base & Reduplication \\
\hline /fómmó/ 'slice' & /foófómmó/ 'just slice’ \\
\hline /kérél 'think' & /keékéré/ 'think' (emphatic) \\
\hline /téiyé/ 'remember' & /teétiéyé/ ' just remember’ \\
\hline /támmá/ ‘jump’ & /taátámmá/ ‘jump’ \\
\hline /lókó/ 'tell' & /lóólókó/ 'tell' (emphatic) \\
\hline
\end{tabular}

Considering the data from table 1, we observe that the base of the RED is verb. We observe from our data that verbs undergo partial reduplication compared to their noun counterpart. Again, from the table we could see that there is lengthening which points to the fact that Anaang is interested in a heavy syllable than the light syllable. It is important also to note that not all the reduplicates conform to the OCP constraint on tone while others do. Adjectives in Anaang also undergo a partial reduplication as demonstrated thus;

TABLE 2

\begin{tabular}{|l|l|}
\hline Adjective & Reduplication \\
\hline /làd/ 'be red' & /làálàd/ 'be red' (emphatic) \\
\hline /nón/ 'be long' & /nóónón/ 'be long' (emphatic) \\
\hline /gád/ 'be dry' & /tgáátád/ 'be dry' (emphatic) \\
\hline /mèm/ 'be soft' & /mèémèm/ 'be soft' (emphatic) \\
\hline
\end{tabular}

As observed earlier, adjectives tend to reduplicate partially. There are of course cases of complete reduplication. Though, Udoh (2010) argues otherwise. He opines that since there is a slight or glaring difference in the tone of the reduplicate, then it should not be called complete. When the complete form of all the segments is copied, it is a complete reduplication. Nouns fall into this category.

TABLE 3

\begin{tabular}{|l|l|}
\hline NOUN & REDUPLICATION \\
\hline /úwiák/ 'pain' & /úwiák!úwiák/ 'full of pain' \\
\hline /átú/ 'heap' & /átú!átú/ 'full of heaps' \\
\hline /ító/ 'face' & /ító!ítfó/ 'just the face' \\
\hline /Ébód/ 'goat' & /ébór!!ébód/ 'full of goats/foolishness' \\
\hline
\end{tabular}

Table 3 shows copying of all the segments of the base to that of the reduplicated form. As noticed also from the data, we see that the first high tone of the second morpheme is down-step, hence the sign (!). This process seems to cut across the complete reduplication and holds well for our concept of OCP. Having looked at some of the morphological constructions in Anaang, let us now consider the applicability of OCP in Anaang.

1. Sensitivity of Anaang reduplicates to the OCP

a. the L-base in reduplication

There are observable cases of OCP in Anaang reduplication. This is because the reduplicated form has a change in its suprasegment (tone), a reason Udoh (2012) argues that there is no complete reduplication since the reduplicated does not copy everything exactly. The L-base in the reduplicated form refers to as reduplication with the low-tone base in partial reduplication. In these set of constructions, the last tone of the RED is dissimilar with the initial tone of the base. Also, the $\mathrm{H}$ base in total reduplication confirms our claim. Consider the following examples:
22 a. /kòn/ 'knock'
b. /kàk/ 'bury'
/kjókón/
/kàá-kàk/
'a command to knock'
c. /boòd/ 'hatch/peel/bòóbòd/
'a command to bury'
'just peel/hatch'

The constraint that allows for this form would be;

\begin{tabular}{|c|c|c|c|c|c|c|}
\hline & RED - kàk & *LRED & MAX-10(S) & IDENT-10(tone) & $* \varnothing \mathrm{N}$ & NOCODA \\
\hline a. & kàk - kàk & $* !$ & & & & $* *$ \\
\hline b. & kà - kák & $* !$ & & $*$ & $*$ & $*$ \\
\hline c. & kàá-kàk & & & & & $*$ \\
\hline d. & kàá - kà & & $* !$ & & $*$ & \\
\hline e. & kàá - kák & & & & & $* !$ \\
\hline
\end{tabular}

Considering the data in tableau 6, we formulate our MCON as * LRED syntactically defined as, anywhere a RED has only a low tone, the violation mark should be assigned. That is why candidates (a) and (b) lost out early in the competition. Our $* \varnothing N$ (NO mono moraic syllable is important because the RED has to have more than a mora to be able to carry the LH contour. The optimal candidate for this competition is candidate (c) because it satisfies or has not violated the higher ranked constraints though it violated the NOCODA CON, it still emerged the winner. The violation of the NOCODA CON by the optimal candidate shows that the NOCODA CON is not too important to the language compared to other CONs in the tableau. This of course is why it is least ranked in the tableau. If for instance the NOCODA CON was ranked higher, then our optimal candidate may not have emerged the winner. 


\section{SUMmARY OF FINDINGS AND CONCLUSION}

From the data analysed, Anaang can be classified as having register and contour tones; the high tone, the low tone, the rising and falling tone, the falling and rising and the down-stepped high tone. The high register tone is seen in all syllable types, that is, both the light and the heavy syllables. The low register tone too can be seen in monosyllabic, disyllabic, trisyllabic words and even more. There is also the rising and falling contour tone that appears on words with one or more syllables. A special feature in Anaang tone is the down-step high tone, a feature the language shares with Ibibio. This happens when one of the tones of a disyllabic word is down-stepped but not to the extent of becoming a low tone. Here, the first tone is the one that is lowered. The down-stepped high tone is represented using an exclamation mark.

Furthermore, Anaang compounds are sensitive to the OCP, nevertheless, the concept works differently in the language. From literature, OCP states that, two identical adjacent tones are not allowed at the morpheme boundary, in our case, it is mostly the second tone of the second morpheme that changes;

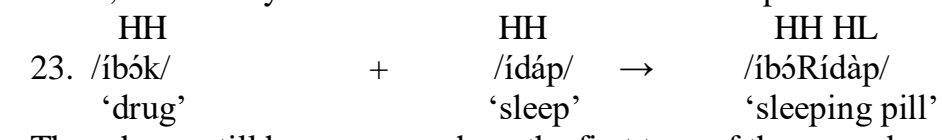

Though, we still have a case where the first tone of the second word changes;

LL LL LLHL

24. /èlèm/ + /èsà/ $\quad=$ /èlèmésà/

'Back' 'yard' 'backyard

The foregoing corroborates Oostendorp (2005) that gives an instance where OCP works differently in some Bantu languages. This lowering of tones is seen in Anaang in tonal structures like; the HH base, the LH base, the LL base, all in compounds. Therefore, we can say that this is an instance of OCP in the Anaang language.

Concerning the sensitivity of reduplication to the OCP in Anaang, we found out that it is attested in both total and partial reduplication. For partial reduplication, OCP is observed when the tone of the base is low while in total reduplication, OCP occurs when the base has a high tone as shown below;

$\begin{array}{cccc}25 . \text { a } / \mathrm{mèn} / & \text { 'swalllow' /meémèn/ 'just swallow' } \\ \text { b. /kuk/ çlose' } & \text { /kuúkulk/ çlose'(emphatic) }\end{array}$

We also have cases where the OCP is not attested during reduplication in Anaang for both complete and partial reduplication. It is important to note that when the tone of the base is high in disyllabic words during partial reduplication, OCP is absent. See below;

26 a. /támmá/ 'jump' /táátámmá/ ‘jump (emphatic)

b. /fóómmó/ 'slice' /fóófómmó/ 'just slice'

This also holds true for complete reduplicates of disyllabic words;

$27 \mathrm{a} . /$ ǹnàn/ 'blind' /ńnànnìnàn/ 'blindly'

b. /nisia/ íntestine' /n’̀iànsia/ 'full of intestines'

As we have seen immediately above in $27 \mathrm{a}$, OCP is seen in the first tone of the second word and in the second tone of the second word in compounds as exemplified above. For reduplication, OCP is prevalent in partial and total reduplication. In partial reduplication, the tone of the base must be low while in total reduplication the tone of the base must be high. In a nutshell, OCP is a very unique feature of the Anaang language because tones in the language are modified depending on the environment they occur especially when they occur at post-lexical constructions.

\section{REFERENCES}

[1] Chomsky, N. \& Halle, M. (1968). The sound pattern of English. New York: Harper \& Row.

[2] Dutta, K. \& Jindal, A. (2016). System for Identification and Analysis of Reduplication Words in Hindi Corpus. International Journal of New Technology and Research (IJNTR), 2(4), 18-21.

[3] Downing, L. (2009). On pitch lowering not linked to voicing: Nguni and Shona group depressor. Language Sciences, 31, 179198.

[4] Goldsmith, J. (1976a). Autosegmental phonology. Ph.D thesis, Massachusetts Institute of Technology.

[5] Goldsmith, J. (1976b). An overview of autosegmental phonology. Linguistic Analysis, 2, 23- 68.

[6] Goldsmith, J. (1995). Autosemental and metrical phonology. Oxford: Basic Blackwell.

[7] Hyman, L. (2001). Tone systems. In M. Haspelmath et al. (Eds.), Language typology and language universals: An international handbook. New York: Walter de Grutyer.

[8] Hyman, L. (2013). African languages \& phonological theory. Bekerley: University of California.

[9] Hyman, L. (2015). How autosegmental is phonology? UC Berkeley Phonology Annual Report.

[10] Katamba, F. (1993). Morphology. London: The Macmilan Press Ltd.

[11] Leben, W. (1973). Suprasegmental phonology. PhD thesis, MIT, Massachusetts.

[12] Lieber, R. (2006). Introducing morphology. Cambridge: Cambridge University Press.

[13] McCarthy, J. (2007). What is optimality theory? Faculty Publication Series 93, University of Massachusetts - Amherst.

[14] McCarthy, J. (2009). OCP effects: Gemmination and antigemmination. Linguistic Inquiry, 17, 207- 263.

[15] Oostendorp, M. (2005). Obligatory contour principle. Unpublished manuscript. 
[16] Prince, A. \& Smolensky, P. (1993). Optimality theory: Constraint interaction in generative grammar. Cambridge, Mass: MIT Press

[17] Salffner, S. (2009). Tone in the phonology, lexicon and grammar of Ikaar. Ph.D thesis, University of London.

[18] Selkirk, E. (1982). The syntax of words. Linguistic Inquiry Monograph Seven.

[19] Spencer, A. (1991). Morphological theory: An introduction to word structure in generative grammar. Oxford \& Cambridge: Basil Blackwell.

[20] Udoh, I. (2010). Vowel deletion in Anaang. Journal of Humanities, 5, 36-51.

[21] Udoh, I. (2012). Anaang phonology: A descriptive sketch. Germany: LAP LAMBERT Academic Publishing.

[22] Yip, M. (2002). Tone. Cambridge: Cambridge University Press.

[23] Yip, M. (2006). Tone Phonology. Encyclopedia of Language \& Linguistics.

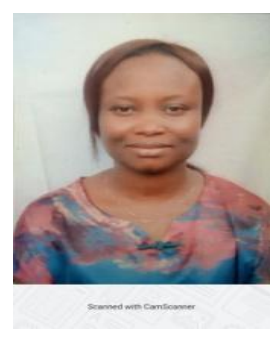

Akpabio, Unwana Akpabio was born on $6^{\text {th }}$ September, 1989 in Ikot Ekpene, Akwa Ibom State, Nigeria. She had her B.A (Hons.) Degree in Linguistics at the University of Uyo in Nigeria, and M. A Degree in Linguistics, with specialty in phonetics and phonology, at the University of Nigeria, Nsukka in 2020. She is looking forward to enrolling for doctoral programme in Linguistics. Unwana is married with children. She loves reading.

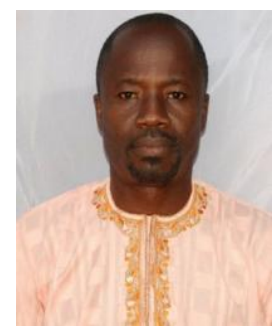

Olusanmi Babarinde was born in Gbongan Osun State on 22nd May, 1974. He had his Bachelor of Arts Degree at the University of Ilorin. He obtained M.A and $\mathrm{PhD}$ degrees in Linguistics at the University of Nigeria in 2006 and 2012 respectively. His area of specialization is phonology, morphology, and language documentation. He is a postdoctoral student in the Department of Linguistics and Nigerian Languages, University of Nigeria Nsukka. He has a number of scholarly publications to his credit. These include "Computer-assisted language instruction and language learning: Evidence from the English-learning Yoruba talking books 1-5. Language Matters: Studies in the Languages of Africa. 50(2), 100-111"; "Theme, diction and prosodic systems in Yoruba lullabies. International Research in Children's Literature, 12(1). 18-33"; A constraint-based analysis of morphological processes in the Ibibio language. Journal of Language Teaching and Research, 11(2), 242-251.

His professional associations include Linguistic Association of Nigeria, Association for the Promotion of Yoruba Language and Culture, and Modern Language Association of Nigeria.

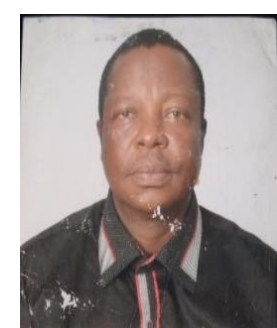

George Okedinachi Iloene is a Senior Lecturer in Linguistics at the University of Nigeria, Nsukka. He taught Linguistics and Igbo Language at Ebonyi State University Abakaliki, Nigeria from 2004 to 2015 before joining the University of Nigeria, Nsukka. His main research interests are phonetics, phonology and Igbo Language. He also has bias for the various interfaces of phonetics and phonology in the Igbo Language. He has published in reputable journals and contributed book chapters both at home and abroad. George Iloene is a Fellow of the American Council of Learned Societies and a three-time attendee of the highly competitive biannual African Linguistics School in 2009, 2011 and 2014 that held in Ghana, Benin Republic and Nigeria respectively. He is currently the editor of Nsukka Journal of Language and Literature (NJALL) of the University of Nigeria, Nsukka. 